\title{
Dietary supplementation with a high dose of daidzein enhances the antioxidant capacity in swine muscle but experts pro-oxidant function in liver and fat tissues
}

\author{
Wei Chen ${ }^{1,2,3,4,5}$, Xianyong Ma $a^{1,2,3,4,5^{*}}$, Yingcai Lin ${ }^{1,2,3,4,5^{*}}$, Yunxia Xiong ${ }^{1,2,3,4,5}$, Chuntian Zheng ${ }^{1,2,3,4,5}$, \\ Youjun $\mathrm{Hu}^{1,2,3,4,5}$, Deqian $\mathrm{Yu}^{1,2,3,4,5}$ and Zongyong Jiang ${ }^{1,2,3,4,5}$
}

\begin{abstract}
Background: Although isoflavones are natural dietary antioxidants, they may have toxicological effects. This study aimed to evaluate the redox system in tissues of finishing pigs by supplementation with high dose of daidzein (640 mg/kg).

Results: The supplementation of high dose of daidzein for $64 \mathrm{~d}$ increased the activity of superoxide dismutase and total antioxidant capacity in longissimus muscle but down-regulated the expression of reactive oxygen species (ROS)-producing enzyme NADPH oxidase-2 and cyclooxygenase-2. In contrast, high-level supplementation with daidzein exerted pro-oxidant changes in back fat, abdominal fat, liver, and plasma, as reflected by increased contents of malondialdehyde, a lipid peroxidation product, in these tissues. Furthermore, daidzein supplementation resulted in higher expression of ROS-producing enzymes, including NADPH oxidase-1 and cyclooxygenase-1 in liver, 5-lipoxygenase (5-LOX) in backfat and NADPH oxidase-2 both in abdominal fat and backfat. The supplementation of daidzein did not affect meat quality parameters in longissimus muscle, including marbling score, eye muscle areas, intramuscular fat, shear force, drip loss, pH and meat color.
\end{abstract}

Conclusions: This experiment suggests that dietary supplementation of finishing pigs with daidzein at a high dose level improves redox status in muscle but exerts pro-oxidant effect in liver and fat tissues.

Keywords: Anti-/pro-oxidant enzyme, Daidzein, Fat, Liver, Muscle, Pigs

\section{Background}

Soy isoflavones, mainly composed of daidzein, genistein and glycitein, are known from in vitro studies to be active scavengers of hydrogen peroxide, hence acting as potential antioxidants. Because of this property [1, 2], isoflavones are considered to be natural dietary antioxidants with interesting benefits to health [3]; there is also potential for their use in animal production to improve growth performance [4]. There is, however, some controversy about the beneficial antioxidant effects of soy isoflavones because, for example, genistein and its

\footnotetext{
*Correspondence: lilymxy80@sohu.com; lyc0123@tom.com

${ }^{1}$ Institute of Animal Science, Guangdong Academy of Agricultural Sciences,

Guangzhou 510640, People's Republic of China

Full list of author information is available at the end of the article
}

methylated derivative, biochanin A, can mobilize nuclear copper in human lymphocytes, leading to degradation of cellular DNA [5]. There is increasing evidence for both antioxidant and pro-oxidant activities of isoflavones, depending upon the specific experimental conditions $[6,7]$. These studies suggest a pro-oxidant potential of high concentrations of isoflavones.

Because of this pro-oxidant potential, one consideration for their application in practical animal production is whether dietary supplementation at high doses of isoflavones might change the redox system in muscle, thereby possibly affecting meat quality. Oxidative stress has been shown to reduce collagen solubility [8], possibly affecting toughness of meat. Direct evidence of negative consequences of high doses of 
isoflavones is still scarce in practical animal production. Accordingly, the objective of present study was to test the effects of dietary supplementation of high dose of the isoflavone daidzein on redox system in skeletal muscle, liver, and back fat and meat quality. The level of supplementation used here, $640 \mathrm{mg} / \mathrm{kg}$ feed, is 15 times higher than that providing optimal antioxidant function [4].

\section{Methods}

The experimental protocol used in this study, including animal management, housing, and slaughter procedures, was approved by the Animal Care and Use Committee of Guangdong Academy of Agricultural Sciences.

\section{Animal and housing}

A total of 48 hybrid finishing pigs (Duroc $\times$ Landrace $\times$ Large White, 24 gilts and 24 barrows) averaging $57 \mathrm{~kg}$ BW were obtained from a single source (a commercial swine farm in South China) and transported to the trial farm. Pigs of each sex were initially blocked into 2 weight groups then randomly assigned to either treated or control groups, each consisting of 6 pens $(2.5 \mathrm{~m} \times$ $2.5 \mathrm{~m}$ ), of 4 pigs ( 2 barrows and 2 gilts) of comparable total starting BW. Pigs in the control group were fed a basal diet that met the NRC [9] recommendation for finishing phase (Table 1). The treated pigs received the basal diet supplemented with $640 \mathrm{mg} / \mathrm{kg}$ daidzein, provided by Guangdong Newland Feed Science \& Technology Co., Ltd.

Pigs were weighed after fasting for $12 \mathrm{~h}$ at the beginning and end of the 64-d finishing period to determine average daily gain (ADG). Feed and water were provided ad libitum throughout the entire experiment period. Average daily feed intake (ADFI) for pigs was calculated as feed offered minus feed refused every $7 \mathrm{~d}$. Average daily gain: feed intake (G:F) was obtained based on ADG and ADFI. On d 64, heparinized blood (10 mL) was collected by jugular venipuncture from 1 gilt and 1 barrow in each pen, $4 \mathrm{~h}$ after feeding $(1400 \mathrm{~h})$. Blood was held on ice until centrifugation $\left(3,000 \times g\right.$ for $15 \mathrm{~min}$ at $\left.4{ }^{\circ} \mathrm{C}\right)$, aliquots of plasma were stored at $-20{ }^{\circ} \mathrm{C}$ for subsequent analysis. The blood-sampled barrows $(n=6$ in each treatment group) were then fasted for $12 \mathrm{~h}$, with water available, weighed on d 65 and electrically stunned and exsanguinated. Back fat, abdominal fat, liver and longissimus muscle $\left(6 / 7^{\text {th }}\right.$ lumbar vertebra level) were immediately sampled, snap-frozen in liquid nitrogen, and stored at $-80{ }^{\circ} \mathrm{C}$ for subsequent analysis. Back fat thicknesses at the first rib, $6 / 7^{\text {th }}, 10^{\text {th }}$, last rib, and the last lumbar vertebra were measured as was longissimus muscle area between the $10^{\text {th }}$ and $11^{\text {th }}$ ribs. Eye muscle areas were measured from digital images of a slice of
Table 1 Composition of the basal diet fed to finishing pigs (as-fed basis)

\begin{tabular}{ll}
\hline Item & Content \\
\hline Ingredient & \\
Corn & 68.7 \\
Soybean & 22.1 \\
Wheat middlings & 6.0 \\
Monocalcium phosphate & 0.7 \\
Limestone, ground & 1.0 \\
Salt & 0.4 \\
L-Lys.HCl & 0.1 \\
Trace-mineral premix & 0.5 \\
Vitamin premix & 0.5 \\
Calculated chemical composition & \\
DE, MJ/kg & 13.40 \\
CP, \% & 16.00 \\
Ca, \% & 0.62 \\
P, total, \% & 0.49 \\
P, available, \% & 0.25 \\
Lys, \% & 0.85 \\
Methinone, \% & 0.24 \\
Met + Cys, \% & 0.50 \\
Thr, \% & 0.60 \\
Trp, \% & 0.18 \\
\hline
\end{tabular}

${ }^{a}$ supplied per kilogram of diet: $12 \mathrm{mg}$ of $\mathrm{Cu}$ (sulfate), $150 \mathrm{mg}$ of $\mathrm{Zn}$ (zinc oxide); $120 \mathrm{mg}$ of Fe (iron sulfate monohydrate), $0.7 \mathrm{mg}$ of I (calcium iodate); $45 \mathrm{mg}$ of $\mathrm{Mn}$ (manganous oxide), and $0.3 \mathrm{mg}$ of Se (sodium selenite)

bsupplied per kilogram of diet: 4,950 IU of vitamin A (acetate), $660 \mathrm{IU}$ of vitamin $D_{3}, 4.8 \mathrm{mg}$ of vitamin $\mathrm{K}$ (menadione sodium bisulfate complex), 2.36 $\mathrm{mg}$ of Vitamin $\mathrm{E}, 16.5 \mathrm{mg}$ of D-pantothenic acid, $6.0 \mathrm{mg}$ of riboflavin, $33.0 \mathrm{mg}$ of niacin, $24.5 \mu \mathrm{g}$ of vitamin $\mathrm{B}_{12}$, and $3.3 \mathrm{mg}$ of vitamin $\mathrm{B}_{6}$

longissimus muscle taken between the $10^{\text {th }}$ and $11^{\text {th }}$ ribs.

\section{Meat quality traits}

The following meat quality measurements were made on longissimus muscle.

\section{Loin color components and $\mathrm{pH}$}

Loin color components and $\mathrm{pH}$ were assayed following the method of Cherel et al. [10]. The CIE L* (lightness), $a^{*}$ (redness), and $b^{*}$ (yellowness) values were determined from a mean of four random readings (two readings for each chop) at $45 \mathrm{~min}$ or $24 \mathrm{~h}$ postmortem using a Minolta chromameter CR-300 (Osaka, Japan), with a D65 illuminant and a 1-cm diameter aperture. The $\mathrm{pH}$ at 45 min, $24 \mathrm{~h}$ or $48 \mathrm{~h}$ postmortem was measured directly in longissimus muscle $\left(7 / 8^{\text {th }}\right.$ rib) using $\mathrm{pH}$ meter (Ingold Xerolyte electrode, Knick pH-meter, Berlin, Germany). 


\section{Drip loss, marbling score and shear force}

After slaughter, two $2.5 \mathrm{~cm}$-thick longissimus muscle chops $\left(10 / 11^{\text {th }}\right.$ rib) were visually evaluated for marbling ( $1=$ devoid to 10 = abundant). The same day, one slices of longissimus muscle (approximately $100 \mathrm{~g}, 9 / 10^{\text {th }} \mathrm{rib}$ to the last rib) were collected, trimmed of external fat and perimysium, weighed, and kept at $4{ }^{\circ} \mathrm{C}$ in a plastic bag for a subsequent $45 \mathrm{~min}, 24 \mathrm{~h}$ or $48 \mathrm{~h}$ for determination of drip loss after muscle were sampled [11]. Drip loss was calculated as a percentage: [(initial weight-final weight)/initial weight $] \times 100$. According to Trefan et al. [12], shear force value (expressed in Newtons) was measured perpendicular to the axis of muscle fibers in 8 replicates for each sample.

\section{Intramuscular fat determination}

Muscle slices were also taken on the last rib longissimus muscle, trimmed of external fat, minced, and freezedried before determination of intramuscular fat content after chloroform-methanol extraction, as described previously [13]. Lipid content of fresh tissue (g/100 g) was calculated by taking into account the dry matter content determined from the weight of minced tissue before and after freeze-drying.

\section{Antioxidant enzyme activity}

Activities of catalase (CAT), glutathione peroxidase (GPx), and total superoxide dismutase (T-SOD), total antioxidant capacity (T-AOC), glutathione-S-transferase (GST) and $\gamma$-glutamylcysteine synthetase $(\gamma$-GCS) in plasma or muscle homogenates were measured in duplicate using commercial assay kits (Nanjing Jiancheng Bioengineering Institute, Nanjing, China) and a plate reader. The oxidized glutathione (GSSG) and reduced glutathione (GSH) concentration in plasma were assayed according to the kit instruction (Nanjing Jiancheng Bioengineering Institute, Nanjing, China). Supernatants, after perchloric acid extraction (muscle and liver homogenized in $4 \mathrm{vol} 1$ $\mathrm{mol} / \mathrm{L}$ cold acid and centrifugation) were used to measure GSSG and reduced GSH content with a kit from the same company. Enzyme activity, GSSG and reduced GSH content in muscle and liver were standardized against protein concentrations.

\section{Plasma prooxidant-antioxidant balance (PAB) assay}

A PAB method, slightly modified from that described by Alamdari et al. [14] was used for assay of plasma. Acetate buffer ( $50 \mathrm{mmol} / \mathrm{L}, \mathrm{pH} 4.5$ ) was used instead of phosphate:citrate buffer and pure 3,3',5,5'-tetramethylbenzidine (TMB) in dimethyl sulfoxide (DMSO) was used instead of reagent tablets. The assay "working solution" was essentially the same and conditions for performing the assay and expressing PAB were almost identical. Full details of the modifications are available upon request. The values
Table 2 Oligonucleotide polymerase chain reaction primers

\begin{tabular}{|c|c|c|}
\hline Gene & Primer sense/antisense & Product length, bp \\
\hline$\beta$-actin & $\begin{array}{l}\text { CCAGGTCATCACCATCGG } \\
\text { CCGTGTTGGCGTAGAGGT }\end{array}$ & 158 \\
\hline $\operatorname{cox} 1$ & $\begin{array}{l}\text { TGGCAACTGCTTCTTCCCTTा } \\
\text { GTGAGCCGACTGAACACCATCTAT }\end{array}$ & 163 \\
\hline $\operatorname{cox} 2$ & $\begin{array}{l}\text { AGCAGGCTGATACTGATAGGAG } \\
\text { TGTTGATAGTTGTACTCGTGGC }\end{array}$ & 224 \\
\hline$G R$ & $\begin{array}{l}\text { GTGAGCCGACTGAACACCATCTAT } \\
\text { CTTCTTCCCGTTGACCTCTACTG }\end{array}$ & 120 \\
\hline$G C L$ & $\begin{array}{l}\text { AACCAGGCTCTCTGCACAATCACTा } \\
\text { TIAGGGTACTGAAACGCGGGTGC }\end{array}$ & 226 \\
\hline NOX2 & $\begin{array}{l}\text { ACCCTITCACCCTGACCTCT } \\
\text { AATCCCTGCTCCCACTAACA }\end{array}$ & 221 \\
\hline NOX4 & $\begin{array}{l}\text { TGGAACGCACTACCAGGATG } \\
\text { TTCGGCACAATACAGGCACA }\end{array}$ & 202 \\
\hline NOX5 & $\begin{array}{l}\text { GCCTGGCGACTACTTGTATCTG } \\
\text { CTTCCTCTGACTCCTTCTCATTITC }\end{array}$ & 226 \\
\hline $5-L O X$ & $\begin{array}{l}\text { GCCAGTGGTTGCGGGCA } \\
\text { GCTTCTCGATITGATGAGCTGGA }\end{array}$ & 183 \\
\hline \multirow[t]{2}{*}{ P450 8B1 } & AAGGATGCGAAGAGAAAACTAGACT & 122 \\
\hline & AGGTGCTTGGTGCTGGCTGA & \\
\hline
\end{tabular}

of the PAB are expressed in arbitrary HK units, being the percentage of hydrogen peroxide in the standard solution.

\section{Determination of tissue MDA content}

The extent of lipid oxidation in plasma, liver, longissimus muscle, backfat and abdominal fat was determined by measuring levels of malondialdehyde (MDA), a secondary lipid oxidation product. The thiobarbituric acid method of Raharjo et al. [15] was used and results were expressed as $\mathrm{nmol} / \mathrm{L}$ for plasma and $\mathrm{nmol} / \mathrm{mg}$ protein in solid tissues; protein was measured by the BCA method.

\section{Isolation of RNA and real-time PCR}

Total RNA was extracted from muscle, liver, backfat and abdominal fat using TRIzol reagent (Invitrogen, Carlsbad, CA, USA) according to the manufacturer's instructions. All RNA samples were treated with DNAase (TAKARA, Dalian, China) and were of high quality as determined by $\mathrm{OD}_{260: 280}$ and evaluation

Table 3 Effects of high-level supplementation with daidzein on growth performance in finishing pigs ${ }^{a}$

\begin{tabular}{lllcc}
\hline Variables & Control & Daidzein & SEM & $P$-value \\
\hline Initial body weight, $\mathrm{kg}$ & 57.45 & 57.47 & 1.06 & 0.99 \\
Final body weight, kg & 110 & 112 & 2.27 & 0.65 \\
Average weight gain, g/d & 914 & 940 & 26.4 & 0.50 \\
Average feed intake, g/d & 2,871 & 3,086 & 53.8 & 0.02 \\
G:F & 0.32 & 0.30 & 0.01 & 0.15 \\
\hline
\end{tabular}

avalues are means $(n=6)$

${ }^{b} \mathrm{G}: F$, average weight gain:feed intake 


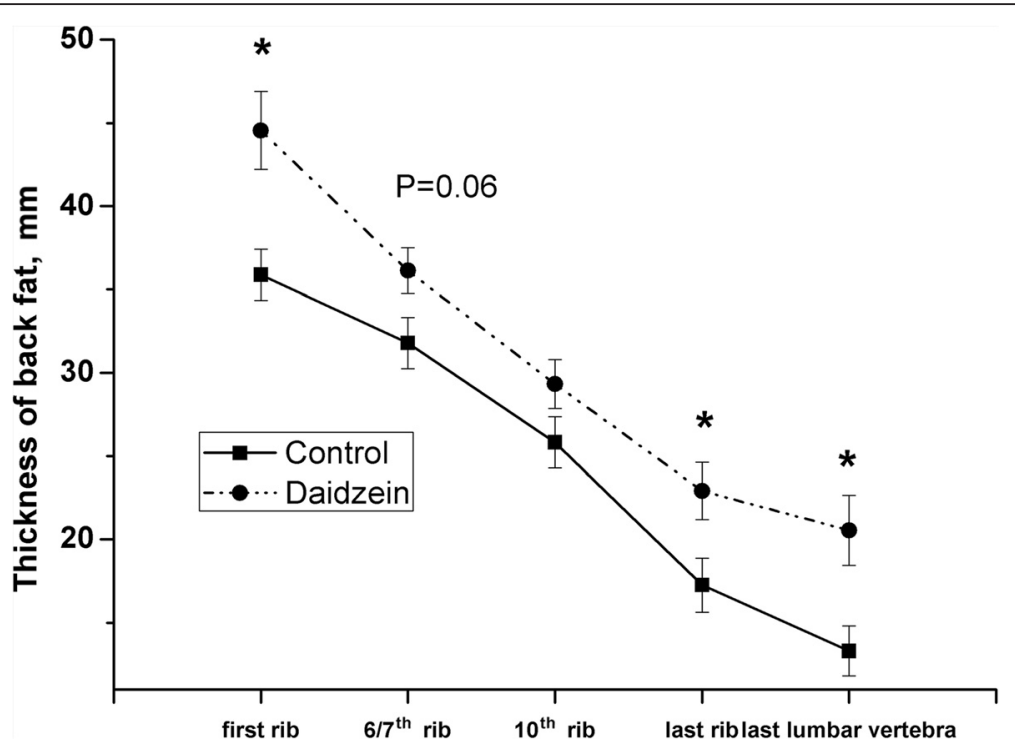

Fig. 1 Effects of high-level supplementation with daidzein on the thickness of backfat in finishing barrows. "**" indicates significantly different from control $(P<0.05)$. Values are means with bars represent "SE ", $n=6$

after gel electrophoresis. Complementary DNA was prepared by reverse-transcription using TAKARA RT reagents according to the manufacturer's instructions. Real-time PCR was performed on $1 \mu \mathrm{L}$ of cDNA product in a total volume of $20 \mu \mathrm{L}$ containing $10 \mu \mathrm{L}$ of SYBR-green PCR master Mix (TAKARA, Dalian, China) and $0.2 \mu \mathrm{mol} / \mathrm{L}$ of gene-specific forward and reverse primers (Table 2). The following protocol was used: denature at $95{ }^{\circ} \mathrm{C}$ for $30 \mathrm{~s}$, followed by 40 cycles of $95{ }^{\circ} \mathrm{C}$ for $20 \mathrm{~s}, 60{ }^{\circ} \mathrm{C}$ for $30 \mathrm{~s}$, and $72{ }^{\circ} \mathrm{C}$ for $20 \mathrm{~s}$. The relative quantification of target gene expression was evaluated by normalizing its signal to that of $\beta$ actin using $2^{-\Delta \Delta C t}$ method [16]. The fold difference in the relative gene expression of target was calculated as the $2^{-\Delta \Delta C t}$ value.

\section{Statistical analysis}

The results are presented as the mean \pm SE. Body weight (initial and ending), ADFI, ADG and G:F were analyzed using one-way ANOVA. Following the method of White et al. [17], the statistical model included dietary supplementation, replicate, and the interaction of dietary supplementation $\times$ replicate as sources of variation. Means were compared using preplanned pairwise $t$-test. Calculations were made using PROC MIXED and PDIFF option (SAS Inst. Inc., Cary, NC). Drip loss, $\mathrm{pH}$ and color of meat were analyzed using one-way ANOVA with repeated measures. The statistical model included dietary supplementation, replicate, time and all two- and three-way interactions as sources of variation. Pig with dietary supplementation $\times$ replicate was used as random variable in the model. Means were compared using a preplanned pairwise $t$-test. Calculations
Table 4 Changes in plasma antioxidant enzymes of finishing pigs fed a high dose of supplemental daidzein ${ }^{a}$

\begin{tabular}{|c|c|c|c|c|}
\hline Variables & Control & Daidzein & SEM & $P$-value \\
\hline \multicolumn{5}{|c|}{$\overline{\gamma-G C S^{b}, U / m L}$} \\
\hline Barrow & 3.46 & 5.23 & 0.49 & 0.05 \\
\hline Gilt & 3.56 & 5.20 & 0.74 & 0.15 \\
\hline \multicolumn{5}{|c|}{$\mathrm{T}-\mathrm{SOD}^{\mathrm{C}}, \mathrm{U} / \mathrm{mL}$} \\
\hline Barrow & 53 & 58.48 & 2.66 & 0.18 \\
\hline Gilt & 54.11 & 53.94 & 3.12 & 0.16 \\
\hline \multicolumn{5}{|c|}{$\mathrm{T}-\mathrm{AOC} \mathrm{C}^{\mathrm{d}}, \mathrm{U} / \mathrm{mL}$} \\
\hline Barrow & 1.49 & 0.98 & 0.23 & 0.16 \\
\hline Gilt & 1.24 & 1.36 & 0.27 & 0.70 \\
\hline \multicolumn{5}{|c|}{$\mathrm{GST}^{\mathrm{e}}, \mathrm{U} / \mathrm{mL}$} \\
\hline Barrow & 21.10 & 18.31 & 1.6 & 0.25 \\
\hline Gilt & 22.38 & 19.27 & 1.28 & 0.12 \\
\hline \multicolumn{5}{|c|}{$\mathrm{CAT}^{f}, \mathrm{U} / \mathrm{mL}$} \\
\hline Barrow & 4.73 & 4.15 & 0.86 & 0.66 \\
\hline Gilt & 3.79 & 3.63 & 0.68 & 0.86 \\
\hline \multicolumn{5}{|l|}{ GSH/GSSG ${ }^{9}$} \\
\hline Barrow & 1.75 & 1.78 & 0.66 & 0.95 \\
\hline Gilt & 1.57 & 1.69 & 0.39 & 0.86 \\
\hline \multicolumn{5}{|c|}{ PAB value ${ }^{h}$} \\
\hline Barrow & 39.31 & 53.19 & 1.17 & $<0.01$ \\
\hline Gilt & 45.02 & 42.96 & 0.74 & 0.23 \\
\hline
\end{tabular}

avalues are means $(n=6)$

${ }^{b} \gamma$-GCS, $\gamma$-glutamylcysteine synthetase activity

'T-SOD, total superoxide dismutase activity

${ }^{\mathrm{d}} \mathrm{T}-\mathrm{AOC}$, total antioxidant capacity

${ }^{\text {e}} \mathrm{GST}$, glutathione-S-transferase activity

${ }^{f} \mathrm{CAT}$, catalase activity

${ }^{9} \mathrm{GSH} / \mathrm{GSSG}$, reduced glutathione/oxidized glutathione

${ }^{h} P A B$, prooxidant-antioxidant balance 
Table 5 Changes in antioxidant indicators in the longissimus muscle of finishing barrows fed a high dose of supplemental daidzein $^{a}$

\begin{tabular}{lcclc}
\hline Variables & Control & Daidzein & SEM & $P$-value \\
\hline GSH/GSSG $^{\text {b }}$ & 0.066 & 0.062 & 0.004 & 0.45 \\
GPx $^{c}$, U/mg pro & 1.16 & 1.13 & 0.27 & 0.94 \\
T-AOC $^{\mathrm{d}}, \mathrm{U} / \mathrm{mg}$ pro & 0.036 & 0.063 & 0.01 & 0.05 \\
T-SOD $^{\mathrm{e}}, \mathrm{U} / \mathrm{mg}$ pro & 14.71 & 17.56 & 0.81 & 0.02
\end{tabular}

${ }^{a}$ Values are means $(n=6)$

${ }^{\mathrm{b}} \mathrm{GSH} / \mathrm{GSSG}$, reduced glutathione/oxidized glutathione

${ }^{\mathrm{C}} \mathrm{GPx}$, glutathione peroxidase activity

d T-AOC, total antioxidant capacity

${ }^{\mathrm{e}} \mathrm{T}-\mathrm{SOD}$, total superoxide dismutase activity

were made using PROC MIXED of SAS with the REPEATED statement. The back fat was analyzed using one-way ANOVA with repeated measures. The statistical model included dietary supplementation, replicate, backfat location and all two- and three-way interactions as sources of variation. Means were compared using preplanned pairwise $t$-tests. Calculations were made using PROC MIXED of SAS, and means were separated using PDIFF option of SAS.

\section{Results}

As shown in Table 3, the ADFI in pigs fed daidzein was $7.5 \%$ greater than control pigs $(P<0.05)$. There were no significant differences between the two groups in average daily gain (ADG) and G:F (Table 3). Compared to the control animals, pigs consuming daidzein had higher back fat thickness $(P<0.05)$ over the first and last ribs, and the last lumbar vertebra (Fig. 1).

The antioxidant indices in plasma are summarized in Table 4. Compared with control, supplementation of daidzein resulted in higher activity of plasma $\gamma$-GCS in barrows but not in gilts. The plasma activities of SOD, GST and CAT were not affected either in barrows or in gilts. The plasma PAB value in barrows fed supplemental daidzein was approximately $35 \%$ greater than in the controls $(P<0.05)$, indicating pro-oxidant potential of daidzein in the circulation.

As shown in Table 5, pigs fed daidzein had higher muscle SOD activity and T-AOC than those of control animals $(P<0.05)$. The mRNA abundances of NADPH oxidase-2 (NOX2) and cooxygenase-2 (COX2) in longissimus muscle were significantly reduced in daidzein-fed pigs but there was no effect on expression of glutathione reductase (GR), glutamate cysteine ligase (GCL), NOX4, NOX5, COX1, 5-lipoxygenase (5-LOX), or cytochrome P450 8B1 (Fig. 2). There were no differences between controls and daidzein-fed barrows in marbling score, eye muscle areas, intramuscular fat content, shear force, drip loss, $\mathrm{pH}$ and color (Table 6), suggesting a negligible daidzein effect in finishing pigs on these indices of meat quality. Compared with control, pigs fed daidzein had higher CAT and SOD activity but had lower GSH/GSSG in liver $(P<0.05$, Table 7$)$.

NOX2 mRNA expression in abdominal fat was $130 \%$ higher in daidzein-fed barrows than control $(P<0.05)$,

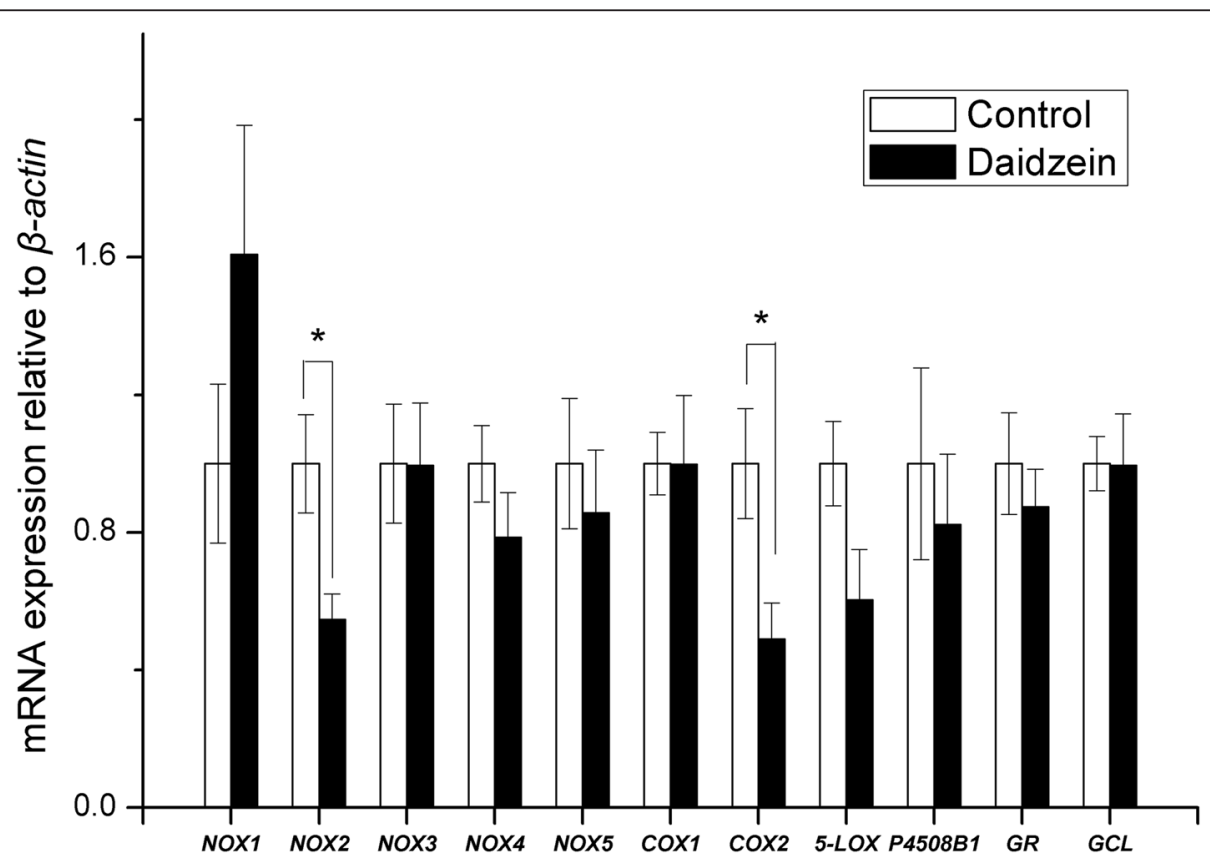

Fig. 2 Effects of high-level supplementation with daidzein on relative transcript abundance of anti/pro-oxidant enzyme genes in muscle of finishing barrows. "**" indicates different from control $(P<0.05)$. Values are means, bars represent "SE", $n=6$. NOX, NADPH oxidase; COX, cyclooxygenase; 5-LOX, 5-lipoxygenase; GR, glutathione reductase; GCL, glutamate cysteine ligase; P4508B1, cytochrome P-450 8B1 
Table 6 Effects of high-level supplementation with daidzein on indices of meat quality in finishing pigs ${ }^{a}$

\begin{tabular}{|c|c|c|c|c|}
\hline Variables & Control & Daidzein & SEM & $P$-value \\
\hline Marbling score ${ }^{b}$ & 3.25 & 3.54 & 0.21 & 0.36 \\
\hline Eye muscle areas, $\mathrm{cm}^{2}$ & 49.97 & 48.92 & 3.85 & 0.85 \\
\hline Intramuscular fat, \% & 2.23 & 1.94 & 0.36 & 0.57 \\
\hline Shear force, Newton & 51.11 & 51.07 & 2.43 & 0.99 \\
\hline \multicolumn{5}{|l|}{ Drip loss, \% } \\
\hline $24 \mathrm{~h}$ & 1.68 & 1.69 & 0.06 & 0.89 \\
\hline $48 \mathrm{~h}$ & 2.47 & 2.35 & 0.11 & 0.47 \\
\hline \multicolumn{5}{|l|}{$\mathrm{pH}$} \\
\hline $45 \mathrm{~min}$ & 6.31 & 6.35 & 0.10 & 0.76 \\
\hline $24 \mathrm{~h}$ & 5.53 & 5.50 & 0.03 & 0.59 \\
\hline $48 \mathrm{~h}$ & 5.54 & 5.48 & 0.07 & 0.55 \\
\hline \multicolumn{5}{|l|}{ Color } \\
\hline \multicolumn{5}{|l|}{$45 \min$} \\
\hline$L^{* c}$ & 44.13 & 44.15 & 1.21 & 0.99 \\
\hline$a^{*}$ & 19.00 & 19.23 & 2.23 & 0.94 \\
\hline$b^{*}$ & 3.41 & 3.20 & 0.62 & 0.82 \\
\hline \multicolumn{5}{|l|}{$24 \mathrm{~h}$} \\
\hline$L^{*}$ & 53.48 & 54.86 & 1.13 & 0.41 \\
\hline$a^{*}$ & 17.90 & 15.93 & 1.58 & 0.40 \\
\hline$b^{*}$ & 3.59 & 3.79 & 0.58 & 0.82 \\
\hline \multicolumn{5}{|l|}{$48 \mathrm{~h}$} \\
\hline$L^{*}$ & 54.54 & 54.90 & 1.22 & 0.84 \\
\hline$a^{*}$ & 16.11 & 15.78 & 0.51 & 0.69 \\
\hline$b^{*}$ & 3.46 & 3.19 & 0.44 & 0.70 \\
\hline
\end{tabular}

${ }^{a}$ Values are means $(n=6)$

${ }^{b}$ Marbling scores: $1=$ devoid to $10=$ moderately abundant or greater 'The $L^{*}$ variable represents lightness, 0 for black and 100 for white; $a^{*}$ represents the intensity in red; and b represents the intensity in yellow

while there were no differences observed in NOX1, NOX4, COX1, COX2, NOX5, 5-LOX and P450 8B1 (Fig. 3). The transcript abundance of both NOX2 and $5-L O X$ in the backfat of daidzein-fed pigs was almost 2 to 3 times higher than that of control $(P<0.05$, Fig. 4$)$. In liver, the gene mRNA abundance of COX1 were

Table 7 Changes in antioxidant indicators in the liver of finishing barrows fed a high dose of supplemental daidzein ${ }^{a}$

\begin{tabular}{lllcl}
\hline Variables & Control & Daidzein & SEM & $P$-value \\
\hline GSH/GSSG $^{\text {b }}$ & 0.16 & 0.07 & 0.03 & 0.03 \\
CAT $^{\mathrm{c}}$, U/mg pro & 79.5 & 96.3 & 2.27 & $<0.01$ \\
T-AOC $^{\mathrm{d}}, \mathrm{U} / \mathrm{mg}$ pro & 0.64 & 0.70 & 0.05 & 0.44 \\
T-SOD $^{\mathrm{e}}, \mathrm{U} / \mathrm{mg}$ pro & 285 & 358 & 16.7 & 0.01 \\
\hline
\end{tabular}

${ }^{a}$ Values are means $(n=6)$

${ }^{\mathrm{b}} \mathrm{GSH} / \mathrm{GSSG}$, reduced glutathione/oxidized glutathione

'CAT, catalase activity

dT-AOC, total antioxidant capacity

${ }^{\mathrm{e}} \mathrm{T}-\mathrm{SOD}$, total superoxide dismutase activity higher in daidzein-fed pigs than control $(P<0.05)$ but $N O X 1$ expression tended to be higher in daidzein-fed pigs $(P=0.06$, Fig. 5$)$. Liver $G C L$ mRNA abundance tended to be higher in daidzein-fed pigs than control $(P=0.07$, Fig. 5).

Plasma concentrations of MDA in daidzein-fed barrows, but not gilts, were $190 \%$ those of controls $(P<0.01$, Fig. 6$)$. Compared with control, the daidzein-fed barrows had higher MDA content in liver, abdominal fat $(P=0.09)$ and back fat $(P<0.01)$ but had lower MDA content in longissimus muscle $(P=0.05)$.

\section{Discussion}

In the present study, consumption of a high level of dietary daidzein increased average feed intake, but the increase did not lead to greater daily gain. Kishida et al. [18] found that dietary supplementation with compound of daidzein and genistein resulted in reduced feed intake in female rats but not in male rats. The present study has shown increased thickness of thoracic and lumbar back fat (first and the last rib and last lumbar vertebra), suggesting a stimulatory effect of daidzein on fat deposition in these finishing barrows. In 3 T3-L1 cells, daidzein enhanced adipocyte differentiation and PPAR $\gamma$ expression in a dose-dependent manner [19], and supplementation of $50 \mathrm{mg} / \mathrm{kg}$ dietary genistein increased the weight of epididymal and renal fat pads in male mice [20]. Other studies show quite different outcomes. Ovariectomized adult female mice, supplemented with $1500 \mathrm{mg} / \mathrm{kg}$ dietary genistein for $3 \mathrm{wk}$ had reduced fat pads and body weight, and increased apoptosis in adipose tissue [21]. Daidzein $(50 \mathrm{mg} / \mathrm{kg} \mathrm{BW}$, i.p.) reduced short-term feed intake of rats and downregulated the fatty acid synthesis-related gene expression in adipose tissue [22]. Daidzein was also shown to inhibit the adipogenesis in mesenchymal stem cells through stimulation of lipolysis [23]. Additionally, administration of $450 \mathrm{mg} /(\mathrm{kg} \times \mathrm{d})$ soy isoflavones caused reduction in the body weight and deposition of visceral adipose tissue in high-fat-diet induced insulin resistant rats [24].

Reactive oxygen species (ROS) are normal metabolic products and play important roles in mediating cell function, including cell signaling [25] and protection against environmental insults, both biological and chemical $[25,26]$. Imbalance between ROS production and scavenging systems results in oxidative injury to proteins, DNA, and lipids [27]. Several enzyme systems contribute to the production of ROS, including NOX, xanthine oxidase, COX and P450 [28] while SOD, GPx and CAT are the principle antioxidant enzymes that eliminate cellular ROS, and GSH provides nonenzymatic defense [29]. These anti-and pro-oxidant systems were evaluated here to assess the pro-oxidant 


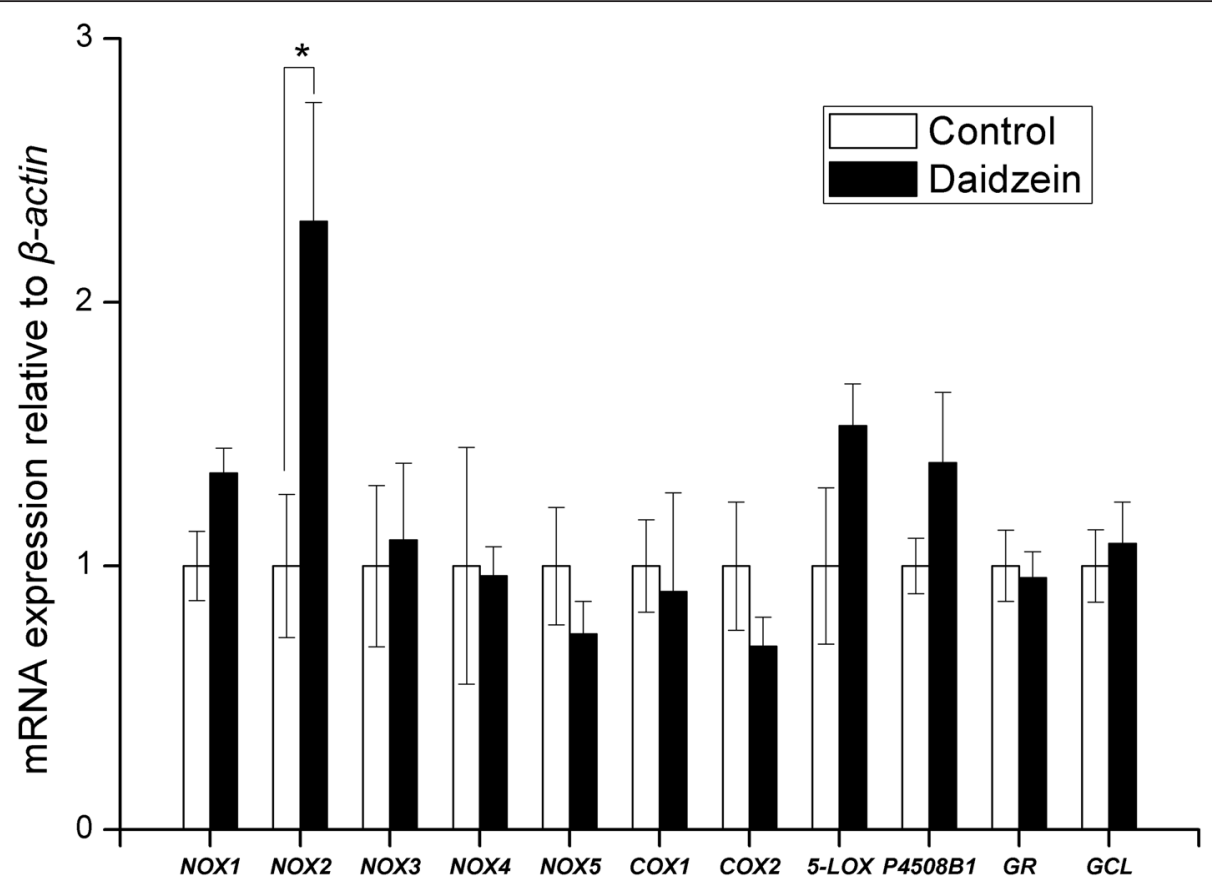

Fig. 3 Effects of high-level supplementation with daidzein on relative transcript abundance of anti/pro-oxidant enzyme genes in liver of finishing barrows. "*" indicates different from control $(P<0.05)$. Values are means, bars represent "SE", $n=6$. NOX, NADPH oxidase; COX, cyclooxygenase; 5-LOX, 5-lipoxygenase; GR, glutathione reductase; GCL, glutamate cysteine ligase; P4508B1, cytochrome P-450 8B1

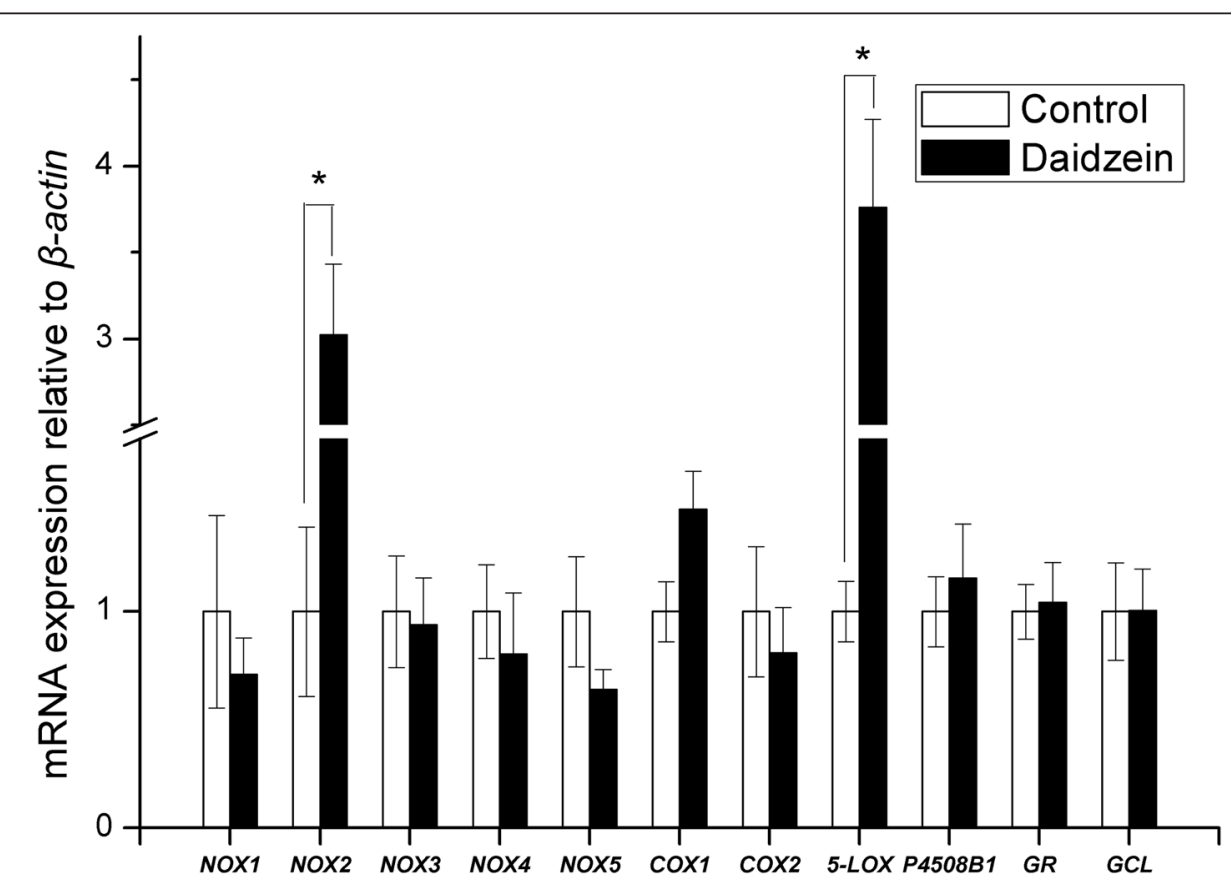

Fig. 4 Effects of high-level supplementation with daidzein on relative transcript abundance of anti/pro-oxidant enzyme genes in backfat of finishing barrows. "**" indicates different from control $(P<0.05)$. Values are means, bars represent "SE", $n=6$. NOX, NADPH Oxidase; COX, cyclooxygenase; 5-LOX, 5-lipoxygenase; GR, glutathione reductase; GCL, glutamate cysteine ligase; P4508B1, cytochrome P-450 8B1 


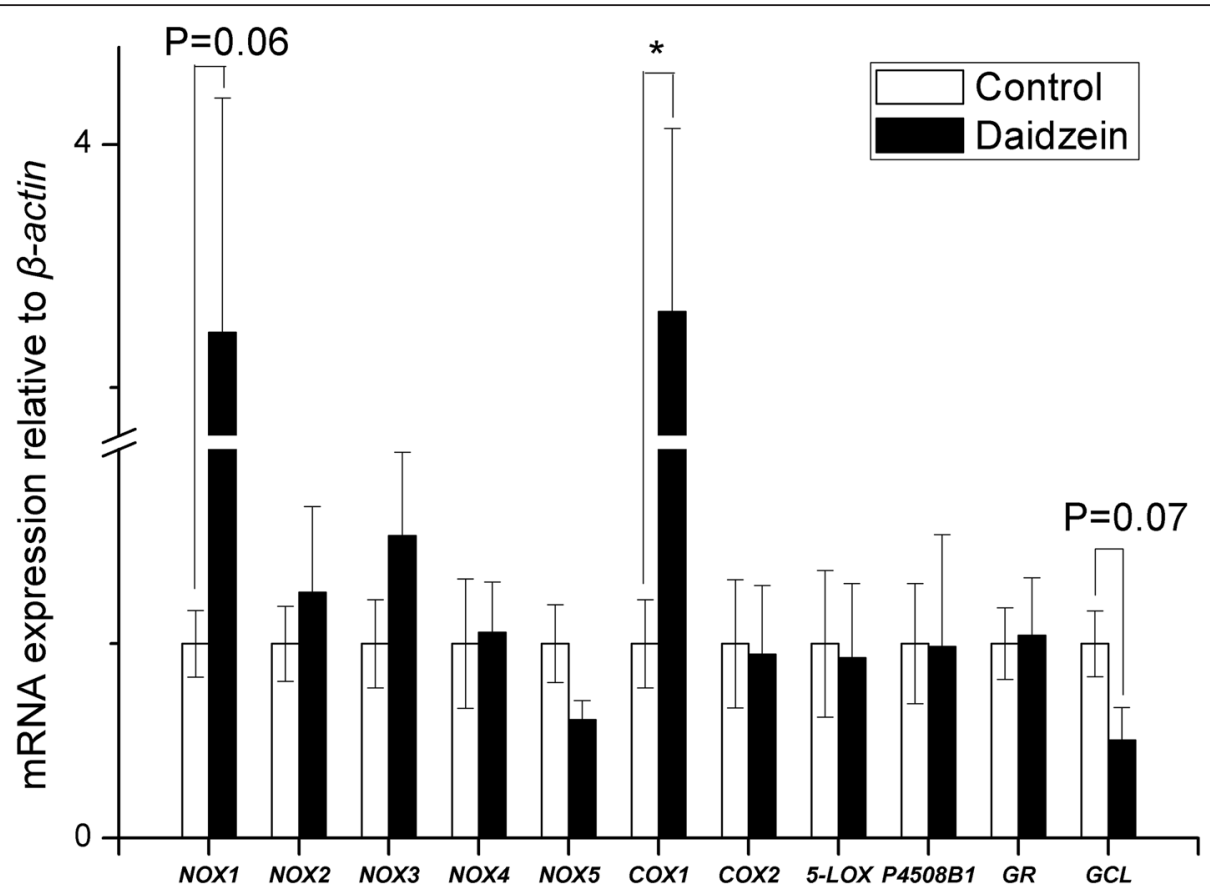

Fig. 5 Effects of high-level supplementation with daidzein on relative transcript abundance of anti/pro-oxidant enzyme genes in abdominal fat of finishing barrows. "** indicates different from control $(P<0.05)$. Values are means, bars represent "SE", $n=6$. NOX, NADPH oxidase; COX, cyclooxygenase; 5-LOX, 5-lipoxygenase; GR, glutathione reductase; GCL, glutamate cysteine ligase; P4508B1, cytochrome P-450 8B1

potential of daidzein, at high level supplementation. The down-regulation of NOX2 and COX2 in longissimus muscle of finishing pigs was unexpected and suggests a suppressive effect of the high dose of daidzein on the pro-oxidant system. Until now, there was no direct evidence of daidzein influencing the NOX system though similar dietary supplementation with genistein $(500 \mathrm{mg} / \mathrm{kg})$ and equol $(250 \mathrm{mg} / \mathrm{kg})$ conferred neuroprotection in rats by reducing NOX activity and upregulating antioxidant genes [30]. Similarly, a moderate

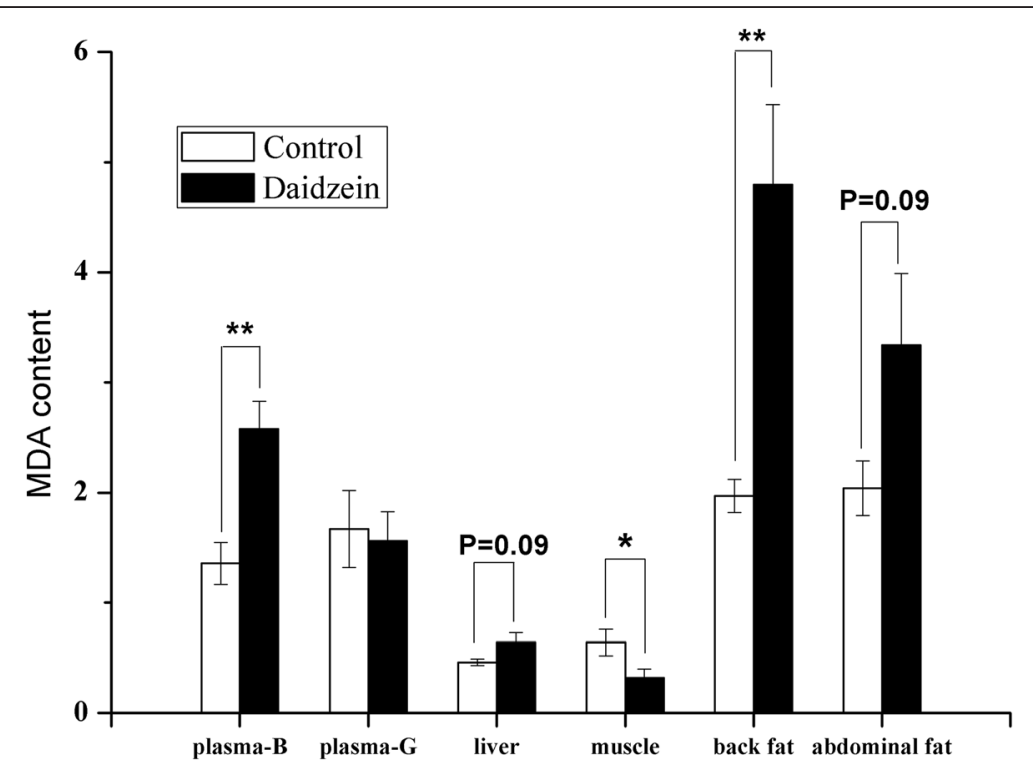

Fig. 6 The effects of high-level dietary supplementation with daidzein on the malondialdehyde (MDA) content in various tissues of finishing pigs. MDA contents are expressed as nmol/mg protein in solid tissues and as nmol/L in plasma (B, barrows; $\mathrm{G}$, gilts). Values are means $(n=6)$, bars represent "SE". "**", "**" indicates significantly different from control $\left({ }^{*} P<0.05,{ }^{* *} P<0.01\right)$ 
concentration of genistein (50 or $100 \mu \mathrm{mol} / \mathrm{L}$ ) suppressed expression of the p22phox NADPH oxidase subunit in aortic endothelial cells from stroke-prone spontaneously hypertensive rats [31]. Consistent with the present results, the inhibitory role of genistein in regulating $\mathrm{NADPH}$ oxidase was also demonstrated in human oral squamous carcinoma cells [32] and in a diabetic mouse model subjected to chronic i.p. treatment with genistein [33].

Another ROS-producing system in oxidative stress, COX, is involved in prostaglandin synthesis [34] and COX2 expression in muscle of the finishing pigs was down-regulated by high-dose supplementation with daidzein. A major metabolite of daidzein, 7,3',4' -trihydroxyisoflavone (THIF), inhibited ultraviolet B-induced COX2 expression through inhibition of nuclear factor (NF-kB) transcriptional activity in mouse epidermal JB6 $\mathrm{P}+$ cells [35]. The enhanced ROS-scavenging enzyme (SOD), as well as the suppressed ROS-inducing enzyme (NADPH oxidase and cyclooxygenase) in the muscle of pigs fed high dose of daidzein, represents the shift towards antioxidant in the pro/antioxidant balance, which finally contributes to the reduced lipid peroxidation in muscle. The present results indicate that high-dose dietary daidzein increased antioxidant enzymes in muscle so both processes contribute to an improved redox status. Despite this outcome, there was no overall effect of daidzein on the meat quality.

In contrast to the effects in muscle, daidzein appeared to exert pro-oxidant potential in liver, back fat and abdominal fat, based on levels of the lipid peroxidation marker MDA in these tissues. There were significant increases in the plasma concentrations of MDA and PAB value in just the barrows, indicating a pro-oxidant effect of the high-level supplementation with daidzein. The increased plasma activity of $\gamma$-GCS is probably a feed-back response to pro-oxidative effects of daidzein. The expression of NOX2 was up-regulated by daidzein both in backfat and abdominal fat, which is contrast to that observed in muscle. Similarly, significant up-regulation of COX1 and NOX1 in liver as well as increased expression of 5-LOX in backfat were also observed in the pigs fed high dose of daidzein. In accordance with the results, the recent report showed that high concentration of genistein, with similar chemical structure to daidzein, increased cellular ROS production by up-regulating 5-LOX [36]. Likewise, it has been reported that LOX mediates the pro-oxidative effect of the anti-oxidant melatonin via stimulation of arachidonic acid metabolism [37]. Lipoxygenases (LOX), an iron-containing dioxygenase, can metabolize arachidonic acid to generate a variety of bioactive eicosanoids, including prostaglandins and leukotrienes [38]. During the catalytic cycle of LOX, peroxyl radical complexes are formed and they can serve as sources of free radicals [39]. The ability of daidzein at high dose to elicit the activation of pro-oxidant enzyme system provides a possible mechanism to explain why lipid peroxidation occurred in fat and liver when fed high dose of daidzein. Still it could not be excluded that the pro-oxidant function may be mediated through its metabolism because it is reported that 7,3',4'-trihydroxyisoflavone $\left(7,3^{\prime}, 4^{\prime}-\mathrm{THIF}\right)$, one of the major metabolites of daidzein was able to increase the ROS production in human cervical cancer cells [40]. The results of this study indicate that daidzein supplementation led to proor anti-oxidant effects in a tissue-dependent manner.

The biological actions of isoflavones vary, depending upon their concentrations. Low concentrations enhance the antioxidant system [3, 4] and protect cells against oxidative stress $[41,42]$ while high concentrations may cause oxidative injury, such as DNA damage and cell death $[36,43]$. The basis for the different effects of daidzein in muscle from other tissues, shown here, is not known but might reflect differential daidzein uptake or sensitivity in the various tissues, possibly related to its lipid solubility.

\section{Conclusion}

In summary, this study has demonstrated that high-level supplementation of a corn-soybean meal diet with daidzein enhances the redox system in the longissimus muscle of finishing pigs by down-regulating the prooxidant system and is without effect on indices of meat quality. At the same time, pro-oxidant responses were apparent in liver and fat tissue, suggesting that tissuedependent actions existed.

\section{Abbreviations}

5-LOX, 5-lipoxygenase; CAT, catalase; COX, cyclooxygenase; DMSO, dimethyl sulfoxide; GCL, glutamate cysteine ligase; GPx, glutathione peroxidase; GR, glutathione reductase; GSH, reduced glutathione; GSSG, oxidized glutathione; GST, glutathione-S-transferase; MDA, malondialdehyde; NOX, NADPH oxidase; P4508B1, cytochrome P-450 8B1; PAB, prooxidant-antioxidant balance; PPARa, peroxisome proliferator-activated receptor alpha; ROS, reactive oxygen species; T-AOC, total antioxidant capacity; TMB, 3,3',5,5'-tetramethylbenzidine; T-SOD, total superoxide dismutase; $\gamma$-GCS, $\gamma$-glutamylcysteine synthetase.

\section{Acknowledgements}

The authors sincerely thank Dr. W. Bruce Currie (Emeritus Professor, Cornell University) for his help in presentation of this manuscript.

\section{Funding}

This study was supported by the "National Natural Science Foundation of China" (Grant No. 31072041), "National Basic Research Program of China (973 Program)" (Grant No. 2012CB124706-4; 2012CB124706-5), Science and Technology Planning Project of Guangdong Province (Grant No. 2013A061401020) and Science and Technology Program of Guangzhou (Grant NO. 2014Y2-00121).

\section{Availability of data and material}

The datasets supporting the conclusions of this article are included within the article. 


\section{Authors' contributions}

WC, XYM, YCL and DQY carried out the animal experiment, data analysis and manuscript writing. YXX, DQY, YJH and WC conducted the biochemical and molecular assay. YCL, CTZ and ZYJ designed the study. All authors read and agreed the final manuscript.

\section{Competing interests}

The authors declare that they have no competing interests.

\section{Consent for publication}

Not applicable.

\section{Ethics approval and consent to participate}

The experimental protocol used in this study, including animal management, housing, and slaughter procedures, was approved by the Animal Care and Use Committee of Guangdong Academy of Agricultural Sciences.

\section{Author details}

'Institute of Animal Science, Guangdong Academy of Agricultural Sciences, Guangzhou 510640, People's Republic of China. ${ }^{2}$ The Key Laboratory of Animal Nutrition and Feed Science (South China) of Ministry of Agriculture, Guangzhou, People's Republic of China. ${ }^{3}$ State Key Laboratory of Livestock and Poultry Breeding, Guangzhou, People's Republic of China. ${ }^{4}$ Guangdong Public Laboratory of Animal Breeding and Nutrition, Guangzhou, People's Republic of China. ${ }^{5}$ Guangdong Key Laboratory of Animal Breeding and Nutrition, Guangzhou, People's Republic of China.

\section{Received: 27 October 2015 Accepted: 16 July 2016}

\section{Published online: 02 August 2016}

\section{References}

1. Record IR, Dreosti IE, Malnerney JK. The antioxidant activity of genistein in vitro. J Nutr Biochem. 1995;6:481-5.

2. Foti P, Erba D, Riso P, Spadafranca A, Criscuoli F, Testolin G. Comparison between daidzein and genistein antioxidant activity in primary and cancer lymphocytes. Arch Biochem Biophys. 2005;433:421-7.

3. Oh HY, Kim SS, Chung HY, Yoon S. Isoflavone supplements exert hormonal and antioxidant effects in postmenopausal Korean women with diabetic retinopathy. J Med Food. 2005;8:1-7.

4. Jiang $Z Y$, Jiang SQ, Lin YC, Xi PB, Yu DQ, Wu TX. Effects of soybean isoflavone on growth performance, meat quality, and antioxidation in male broilers. Poult Sci. 2007;86:1356-62.

5. Ullah MF, Shamim U, Hanif S, Azmi AS, Hadi SM. Cellular DNA breakage by soy isoflavone genistein and its methylated structural analogue biochanin A. Mol Nutr Food Res. 2009;53:1376-85.

6. Halliwell B. Are polyphenols antioxidants or pro-oxidants? What do we learn from cell culture and in vivo studies? Arch Biochem Biophys. 2008;476:107-12.

7. Ziberna L, Lunder M, Moze S, Vanzo A, Tramer F, Passamonti S, et al. Acute cardioprotective and cardiotoxic effects of bilberry anthocyanins in ischemia-reperfusion injury: beyond concentration- dependent antioxidant activity. Cardiovasc Toxicol. 2010;10:283-94.

8. Archile-Contreras AC, Purslow PP. Oxidative stress may affect meat quality by interfering with collagen turnover by muscle fibroblasts. Food Res Int. 2011:44:582-8.

9. NRC. Nutrient Requirements of Swine. 10th ed. Washington, DC: National Academy Press; 1998.

10. Cherel P, Herault F, Vincent A, Le Roy P, Damon M. Genetic variability of transcript abundance in pig skeletal muscle at slaughter: Relationships with meat quality traits. J Anim Sci. 2012;90:699-708.

11. Lefaucheur L, Lebret B, Ecolan P, Louveau I, Damon M, Prunier A, et al. Muscle characteristics and meat quality traits are affected by divergent selection on residual feed intake in pigs. J Anim Sci. 2011;89:996-1010.

12. Trefan L, Doeschl-Wilson A, Rooke JA, Terlouw C, Bünger L. Meta-analysis of effects of gender in combination with carcass weight and breed on pork quality. J Anim Sci. 2013;91:1480-92.

13. Lebret B, Meunier-Salaün MC, Foury A, Mormède $P$, Dransfield E, Dourmad $J Y$. Influence of rearing conditions on performance, behavioral, and physiological responses of pigs to preslaughter handling, carcass traits, and meat quality. J Anim Sci. 2006;84:2436-47.

14. Alamdari DH, Paletas K, Pegiou T, Sarigianni M, Befani C, Koliakos G. A novel assay for the evaluation of the prooxidant-antioxidant balance, before and after antioxidant vitamin administration in type II diabetes patients. Clin Biochem. 2007;40:248-54.

15. Raharjo S, Sofos JN, Schmidt GR. Solid-phase acid extraction improves thiobarbituric acid method to determine lipid oxidation. J Food Sci. 1993; $58: 921-4$

16. Livak KJ, Schmittgen TD. Analysis of relative gene expression data using real-time quantitative PCR and the $2^{-\Delta \Delta C T}$ method. Methods. 2001;25:402-8.

17. White NR, Burns PD, Cheatham RD, Romero RM, Nozykowski JP, Bruemmer JE, et al. Fish meal supplementation increases bovine plasma and luteal tissue omega-3 fatty acid composition. J Anim Sci. 2012;90:771-8.

18. Kishida T, Mizushige T, Ohtsu Y, Ishikawa S, Nagamoto M, Izumi T, et al. Dietary soy isoflavone-aglycone lowers food intake in female rats with and without ovariectomy. Obesity. 2008;16:290-7.

19. Kone $\mathrm{OH}$. The combined effects of genistein and daidzein on adipocyte differentiaon. Thesis: University of Massachusetts-Amherst; 2014.

20. Penza M, Montani C, Romani A, Vignolini P, Pampaloni B, Tanini A, et al. Genistein affects adipose tissue deposition in a dose-dependent and gender-specific manner. Endocrinology. 2006;147:5740-51.

21. Kim HK, Nelson-Dooley C, Della-Fera MA, Yang JY, Zhang W, Duan J, et al. Genistein decreases food intake, body weight, and fat pad weight and causes adipose tissue apoptosis in ovariectomized female mice. J Nutr. 2006;136:409-14.

22. Crespillo A, Alonso M, Vida M, Pavón FJ, Serrano A, Rivera P, et al. Reduction of body weight, liver steatosis and expression of stearoyl-CoA desaturase 1 by the isoflavone daidzein in diet-induced obesity. Brit J Pharmacol. 2011; 164:1899-915.

23. Kim MH, Park JS, Seo MS, Jung JW, Lee YS, Kang KS. Genistein and daidzein repress adipogenic differentiation of human adipose tissue-derived mesenchymal stem cells via Wnt/ $\beta$-catenin signalling or lipolysis. Cell Prolif. 2010:43:594-605.

24. Zhang HM, Chen SW, Zhang LS, Feng XF. The effects of soy isoflavone on insulin sensitivity and adipocytokines in insulin resistant rats administered with high-fat diet. Nat Prod Res. 2008;22:1637-49.

25. West JD, Marnett $L$ J. Endogenous reactive intermediates as modulators of cell signaling and cell death. Chem Res Toxicol. 2006;19:173-94.

26. Nguyen T, Sherratt PJ, Pickett CB. Regulatory mechanisms controlling gene expression mediated by the antioxidant response element. Annu Rev Pharmacol Toxicol. 2003:43:233-60.

27. Liebler DC. The poisons within: application of toxicity mechanisms to fundamental disease processes. Chem Res Toxicol. 2006;19:610-3.

28. Valko M, Leibfritz D, Moncol J, Cronin MT, Mazur M, Telser J. Free radicals and antioxidants in normal physiological functions and human disease. Int J Biochem Cell Biol. 2007;39:44-84.

29. Armstrong JS, Steinauer KK, Hornung B, Irish JM, Lecane P, Birrell GW, et al Role of glutathione depletion and reactive oxygen species generation in apoptotic signaling in a human B lymphoma cell line. Cell Death Differ. 2002;9:252-63.

30. Ma YL, Sullivan JC, Schreihofer DA. Dietary genistein and equol (4', 7 isoflavandiol) reduce oxidative stress and protect rats against focal cerebral ischemia. Am J Physiol Regul Integr Comp Physiol. 2010;299:871-7.

31. Xu JW, Ikeda K, Yamori Y. Genistein inhibits expressions of NADPH oxidase p22phox and angiotensin II type 1 receptor in aortic endothelial cells from stroke-prone spontaneously hypertensive rats. Hypertens Res. 2004;27:675-83.

32. Ye F, Wu J, Dunn T, Yi J, Tong X, Zhang D. Inhibition of cyclooxygenase2 activity in head and neck cancer cells by genistein. Cancer Lett. 2004; 211:39-46.

33. Elmarakby AA, Ibrahim AS, Faulkner J, Mozaffari MS, Liou Gl, Abdelsayed R. Tyrosine kinase inhibitor, genistein, reduces renal inflammation and injury in streptozotocin-induced diabetic mice. Vascul Pharmacol. 2011;55:149-56.

34. Beak SM, Lee YS, Kim JA. NADPH oxidase and cyclooxygenase mediate the ultraviolet B-induced generation of reactive oxygen species and activation of nuclear factor-kappa B in HaCa T human keratinocytes. Biochimie. 2004. 86:425-9.

35. Lee DE, Lee KW, Byun S, Jung SK, Song N, Lim SH, et al. 7,3',4'Trihydroxyisoflavone, a metabolite of the soy isoflavone daidzein, suppresses ultraviolet B-induced skin cancer by targeting Cot and MKK4 J Biol Chem. 2011;286:14246-56.

36. Chen W, Lin YC, Ma XY, Jiang ZY, Lan SP. High concentrations of genistein exhibit pro-oxidant effects in primary muscle cells through mechanisms involving 5-lipoxygenase-mediated production of reactive oxygen species. Food Chem Toxicol. 2014;67:72-9. 
37. Radogna F, Sestili P, Martinelli C, Paolillo M, Paternoster L, Albertini MC, et al. Lipoxygenase-mediated pro-radical effect of melatonin via stimulation of arachidonic acid metabolism. Toxicol Appl Pharmacol. 2009;238:170-7.

38. Kim C, Kim JY, Kim JH. Cytosolic phospholipase A(2), lipoxygenase metabolites, and reactive oxygen species. BMB Rep. 2008;41:555-9.

39. Yun MR, Park HM, Seo KW, Lee SJ, Im DS, Kim CD. 5-Lipoxygenase plays an essential role in 4-HNE-enhanced ROS production in murine macrophages via activation of NADPH oxidase. Free Radic Res. 2010;44:742-50.

40. Lo YL, Wang W, Ho CT. 7, 3', 4'-Trihydroxyisoflavone modulates multidrug resistance transporters and induces apoptosis via production of reactive oxygen species. Toxicology. 2012;302:221-32.

41. Moore JO, Wang Y, Stebbins WG, Gao D, Zhou X, Phelps R, et al. Photoprotective effect of isoflavone genistein on ultraviolet B-induced pyrimidine dimer formation and PCNA expression in human reconsitituted skin and its implications in dermatology and prevention of cutaneous carcinogenesis. Carcinogenesis. 2006;27:1627-35.

42. Iovine B, lannella ML, Gasparri F, Monfrecola G, Bevilacqua MA. Synergic effect of genistein and daidzein on UVB-Induced DNA damage: An effective photoprotective combination. J Biomed Biotechnol. 2011; doi: 10.1155/ 2011/692846

43. Fox JT, Sakamuru S, Huang R, Teneva N, Simmons SO, Xia M, et al. Highthroughput genotoxicity assay identifies antoixdants as inducers of DNA damage response and cell death. Proc Natl Acad Sci U S A. 2011;109:5423-8.

\section{Submit your next manuscript to BioMed Central} and we will help you at every step:

- We accept pre-submission inquiries

- Our selector tool helps you to find the most relevant journal

- We provide round the clock customer support

- Convenient online submission

- Thorough peer review

- Inclusion in PubMed and all major indexing services

- Maximum visibility for your research

Submit your manuscript at www.biomedcentral.com/submit

) Biomed Central 